Araştırma Makalesi / Research Article

\title{
TERKIBİ ARAYAN AYDIN: AHMET HAMDİ TANPINAR
}

\author{
Ömer Faruk YÜCEL*
}

\section{INTELLECTUAL WHO SEEK COMPOSITION: AHMET HAMDI TANPINAR}

\begin{abstract}
$\ddot{O} z$
Toplumu her yönüyle "yeni" ve "Batılı" ilerleme anlayışında değiştiren modernleşme, Türk toplum ve devlet yapısına 19. yüzyıldan itibaren girmeye başlamıştır. Batı dışı toplum ve devlet yapısına sahip ülkeler Batının dinamiklerinden ve gelişim aşamalarından mahrumdur. Bu yüzden modernleşme / batılılaşma vakıası Türk İslâm kültür ve geleneği içinde birtakım meseleleri de beraberinde getirmiştir. $\mathrm{Bu}$ meselelerin aşılmasında toplumun düşüncelerini temsil eden gazeteci - sanatçı - bilim adamı olan aydınların önemli bir etkisi söz konusudur. Türk modernleşmesinde de aydınların önemli rolü vardır. Bu çalışma, Cumhuriyet devri aydınlarından Ahmet Hamdi Tanpınar'ın görüş, düşünce ve kanaatleriyle nasıl bir aydın kimliği ortaya koyduğunu ele almaktadır. Muhtelif eserlerinde Tanpınar, bizzat kendi aydın kişiliğini yansıtır. Doğu Batı arasında müşterek bir bağ inşa eden, "terkibin peşinde" bir aydın olarak Tanpınar'ın muhtelif eserleri, modernleşme, Türk modernleşmesi ve aydın kavramlarının teorik temelleri ışığında incelenmiştir.
\end{abstract}

Anahtar Kelimeler: Modernleşme, Aydın, Türk Modernleşmesi, Tanpınar.

\begin{abstract}
Modernization, which changed the society in understanding of "new" and "westerner" advancement in all aspects, has started to enter Turkish society and state structure since 19th century. The countries which are non-western society and state structure are deprived of the dynamics and advancement phases of the West. Therefore, modernization / westernization fact has brougt along some issues within the Turkish İslamic culture and tradition. Intellectuals who are journalist artist - scientist and represent the thoughts of the society have an important effect in overcoming these issues. Intellectuals also have important role in Turkish modernization. This study examines what kind of intellectual identity Ahmet Hamdi Tanpınar, one of the intellectuals of the Republician era, revealed with his views, thoughts and opinions. Tanpinar reflects his own intellectual personality in various works. Various works of Tanpınar as an intellectual "pursuing the composition", building a common link between the East and West, were examined
\end{abstract}

* Arş Gör., Gazi Üniversitesi, e-posta: omerfarukyucel4@gmail.com, https://orcid.org/0000-0002-3035-004X.

Makale Gönderim Tarihi: 12.06.2020 https://doi.org/10.11616/basbed.v20i56819.752122 Makale Kabul Tarihi : :04.09.2020 
in the light of the theoretical foundations of modernization, Turkish modernization and intellectual concepts.

Keywords: Modernization, Intellectual, Turkish Modernization, Tanpınar.

\section{Giriș}

\subsection{Modernlik ve Modernleşme Kavramlarına Dair}

Ortaçağ, kilise ve dogmatik düşüncenin hâkim olduğu, aklın ikinci plana atıldığı bir dönem olarak özellikle Batı toplumlarının gelişiminin önünde bir engel teşkil etmiştir. 16. yüzyılla birlikte Rönesans ve Reform hareketleri denilen kilisenin tahakkümüne karşı çıkan ilmî ve kültürel bir hareket başlamıştır. Kopernik ve Newton'un bilimsel çalışmaları, dinî değerlerin ve doğru olduğu kabul edilen şeylerin yerine akıllc1lı̆ı ön plana koymak suretiyle yeni bir anlayışın doğması yönündeki çabalardır.

"Modernlik" olgusu işte bu sürecin bir parçası olarak ortaya çıkmıştır. Jeannierre'e göre moderniteye geçiş, bilimsel, siyasî, kültürel ve teknikendüstriyel devrim olmak üzere dört aşamada oluşmuş̧ur. Genellikle Newton ile başlatılan bu süreçte rasyonalist ve determinist bir anlayış ile bilimin kesinlik düzeyinde elde ettiği bilgilerin insan, doğa ve Tanrı karşısında farklı bakış açılarının değerlendirilmesi söz konusu olmuştur. İngiltere ve ABD ile başlayan siyasî devrim Fransız devrimi ile birleşerek modern siyasî yönetim biçimi olarak demokrasiye zemin hazırlamıştır. Kültürel devrimde laiklik, dinin eleştirisi gibi alınarak rasyonelleşmenin her sahaya tatbiki ile mümkün olmuştur. "Doğa, artık Tanrının insan için kurduğu bir ev değildir; insan artık özerk ve kendini düzenleyen bir doğanın içinde yaşamaktadır." (Jeanniere, 2000).

Modernleşme, Batıda, hayatın her sahasına nüfuz eden bir vakıa olarak ortaya çıkmışıı. $\mathrm{Bu}$ vakıa, bir yandan insan hayatını kolaylaştıran yenilikler getirmiş öte yandan toplum hayatının gerek kültürel gerek siyasî alanda değişmesine ve bu değişimle beraber bazı tartışmaların vuku bulmasına neden olmuştur. Bu tartışmalar üzerinde pek çok sosyal bilimci, görüş ve düşüncelerini ortaya koymuştur.

Habermas, Weber'in modernleşme kuramından hareketle bir modernleşme kavramı türetir. Bilim, ahlâk ve sanat alanlarının birbirinden ayrışmasını öngören ve farklı uzmanlık alanlarının gelişmesine neden olan Aydınlanma felsefesi tabanlı- modernleşme, günlük yaşamda kullanılmayan bir dilin oluşumuna neden olmuştur. Nitekim bu farklılık özgürleştirici değil ayrıştırıcıdır. Bu da modernizm ve Aydınlanmanın temeline ters düşer. Weber bu süreci anlam ve özgürlük kaybı olarak değerlendirmiştir (Atiker, 1998: 23-28). 
Daniel Bell, modernizmin kültürel boyutu üzerinde durmuştur. Marksist yaklaşım, altyapının üstyapıyı belirleyeceği görüşünü savunarak kültürün de ekonomik hayata bağl1 bir gelişim göstereceğini öne sürmektedir. İşte Bell, bu düşünceye karşı çıkmış ve kültürün tarihî süreç ile bir bütün teşkil ettiğini belirtmiştir. Teknik ilerleme eskinin kullanımını ortadan kaldırsa da kültürel değişme, eskiyi ortadan kaldırmaz, onunla bir sentez oluşturur. Bu yüzden farklı bir gelişme sürecine sahiptir ${ }^{1}$ (Atiker, 1998: 42-44).

Anthony Giddens, modernliğin özelliklerini belirlediği eserinde kavramın üç ana boyutuna dikkat çekmiştir: "zaman ve mekânın ayrılması, yerinden çıkarma düzeneklerinin gelişmesi ve bilginin düşünümselliği”. Modernlik, zaman ve mekânın, teknolojik ve iktisadî gelişme ve bunların yeniden üretilmesinin sağlanması adına ayrılmasına neden olmuştur. Zaman ve mekân kavramı geleneksel toplumda olduğu gibi yerleşik bir alana değil, büyük ölçüde toplum ilişkilerine göre yeniden şekillendirilir. Bilgi üretimi de gene geleneksel değerlerin bağlamından koparılarak modernliğin özüne uygun bir şekilde yeniden oluşturulur. Giddens'a göre (1998) modernliğin dönüştürdüğü unsurlar şu maddelerde özetlenebilir:

- Modernlik, kapitalist iktisadî sistem ve küreselleşme ile kendini yeniden üretir. Bu unsurlar zaman-mekân kavramının da geniş yelpazede hareketine neden olur.

- Ulus-devletler, geleneksel devletlerin aksine modernliğin bir kurumu olarak belirir.

- Güven duygusu, uzmanlık ve modernliğin ilmî gelişmesi içerisinde bireyi kendi gelişimine yöneltmiştir.

- Dinî değerler ve geçmişe yönelik kültürel değerlerden ziyade geleceğe dönük bir ilerleme anlayışı ortaya çıkmıştır.

- Uluslararası ticaret ve askerî birleşmeler modernliğin bir diğer sonucudur.

- İktisadî büyüme, savaş ve çevre kirliliği modernliğin riskleri olarak kaydedilir.

Özetle modernleşme, Batıda ortaya çıkan ve geleneğe karşı hayatın her sahasında yeniliği öngören bilimsel, iktisadî ve kültürel bir harekettir. Bat1, kendi içinde modernliği oturtabilmek için şüphesiz pek çok sıkıntı çekmiştir. Fakat yüzyıllar içinde rasyonalizmle başlayarak, pozitivist bilim

${ }^{1}$ Bell'in bu düşünceleri Türk bilim adamlarından Erol Güngör'ün kültür ve medeniyet anlayışı ile benzerlik göstermektedir. Zira Güngör de kültürde eski kavramının olmayacağını, aksine geçmiş değerlerin yeni olandan daha değerli olabileceğini vurgulamaktadır. 
anlayışı ve liberal siyasî düzen ile birlikte kendini bir rol model olarak dünyaya sunmuştur. Modernleşmenin bu temel nitelikleri her toplumda eşit bir oranda gerçekleşmemiştir. Toplum yapısı, din ve kültürel değerler, gelenekselden modernliğe geçen toplumlar için önemli meselelere yol açmıştır. Türk modernleşmesi de bu sancılı sürecin bir örneğini temsil eder.

\subsection{Türk Modernleşmesi}

Batıda meydana gelen iktisadî, sosyal, bilimsel ve kültürel gelişmeler, modernliğin nitelikleri sebebiyle Batı dışı toplumları da doğrudan veya dolaylı olarak etkilemiştir. 19. yüzyıla gelindiğinde geleneksel değerlerinden sıyrılarak modern bir görünüme ulaşan Batı medeniyetinin dışında kalan devletler, modern yani gelişmiş olamadıkları için "geri kalmış", "geleneksel" gibi nitelemelere maruz kalmıştır. Bunun önüne geçebilmenin reçetesi de modernleşme veya "Batılılaşma" politikalarıdır.

Batı dışı bir toplum ve devlet yapısına sahip olan Osmanlı İmparatorluğu da bu sürecin dışında kalamamış ve geri kalışının sebeplerini "modern" olamayışında görmüştür. İşte Osmanlı/Türk modernleşmesi bu noktada başlamıştır. Osmanlı Devleti, toprak kayıpları ve askerî yenilgiler sonrasında III. Selim Devri'nde ilk olarak Batılılaşma adımları atmış ve Nizam-1 Cedit Ordusunun ${ }^{2}$ kurulması ile başarısızlığı telafi etmeye çalışmıştır.

III. Selim sonrasında Batılılaşma hamleleri II. Mahmut devrinde daha güçlü bir şekilde devam etmiş, modern devlet anlayışına uygun bazı kurumların temelleri atılmıştır. Bununla birlikte, Hilmi Ziya Ülken’e göre (2015: 27), Batılılaşma hareketinin siyasî ve hukukî bir boyut kazanması, Abdülmecit döneminde Reşit Paşa tarafından hazırlanan ve temeli tebaanın eşitlik, can, mal ve mülk güvenliğine dayanan Tanzimat Fermanı (1839) ile gerçekleşmiştir. 1856 tarihli Islahat Fermanı bu hareketin bir devamı olarak kabul edilmiş ve Osmanlıda özellikle azınlıkların haklarını savunan bir metin olarak ortaya çıkmıştır. ${ }^{3}$

\footnotetext{
${ }^{2}$ Niyazi Berkes'e göre Nizam-1 Cedit reformu, yalnızca askerî değil aynı zamanda iktisadîdir. Zira yeni ordunun tesisi için ek kaynak tahsisi gereklidir. Bunun için İrad-1 Cedit hazinesi kurulmuş, bu da halka ek vergi külfeti olarak yansıdığından içtimaî huzursuzluklara neden olmuştur. Buna bir de gelenekçi ve siyasî-kültürel bir güç olarak Yeniçerilerin isyanı eklenmiş, malî bunalım ve siyasî istikrarsızlıkla beraber Nizam-1 Cedit reformu hedeflenen başarıya ulaşamamıştır (Berkes, 2017: 100-120).

${ }^{3}$ Bernard Lewis'e göre (1998: 27), Tanzimat ve Islahat Fermanları ve Kanun-1 Esasi gibi inkılap hareketleri, Osmanlı'nın Batı desteğine ihtiyacının olduğu 690
} 
Tanzimat kadroları, devletin Batılılaşması için bir dizi hukukî, idarî ve iktisadî değişmelerin gerçekleşmesinde rol oynamıştır. Bu dönemde ortaya çıkan Genç Osmanlı hareketi, Tanzimatçılara karşı bir eleştiri getirmişlerdir. Bunlardan bazıları; Batıyı kandırmak için yapılmış olan siyasî bir manevra, keyfî̀ ve mutlakiyetçi bir hükümet, şeklî değişimler, gayrimüslimlerin üstün görülerek sıradan halkın Batılı eşitliğe reva görülmeyişi olarak özetlenebilir. Genç Osmanlıların bunlara karşı çözüm önerileri ise meşrutî yönetim ve meşveret usulünün oturtulması gerekliliğidir (Lewis, 1998: 169).

II. Abdülhamit döneminde Meşrutiyet ilan edilmiş fakat kısa bir süre sonra meclis tatil edilmiş, "İstibdat" devri olarak değerlendirilen dönem başlamıştır. Meşrutiyete giden yolda, Şinasi, Namık Kemal ve Ziya Paşa'nın rolü büyük olmuştur. Gazetenin kurulmasından sonra, Batılılaşma hareketi kısmen de olsa halka inmeyi başarmış, bunda da devrin gazeteci, memur ve fikir adamları olarak Genç Osmanlıların büyük tesiri vardır. ${ }^{4}$ Şinasi'nin Tasvir-i Efkâr'ı öncü bir rol oynamış, onu Namık Kemal' in Ibret'i ve Londra'da Ziya Paşa'nın kurduğu Hürriyet ve diğer Türk gazeteleri takip etmiştir (Ülken, 2015: 35).

Her ne kadar baskıcı bir rejim olduğu söylense de II. Abdülhamit döneminde Batılılaşma hamleleri, 93 Harbi'nin sıkıntılarına rağmen hız kesmeden, hatta belki de artarak devam etmiştir. Bu süreçte kurulan yeni askerî okul ve Tibbiye gibi kurumlar modern eğitimi getirmiştir. Yine bu dönemde Ahmet Midhat gibi gazeteci ve edebiyatçılar, halk1 eğitme vazifesi üstlenerek Batı edebiyatı ve hayatını Osmanl1-Türk topraklarına sokmuştur. $^{5}$

II. Meşrutiyet devrine hâkim olan İttihat ve Terakki, Batılılaşma politikasını sürdürmüş, fakat devre damgasını vuran Balkan, I. Dünya ve Kurtuluş Savaşları, Osmanlı'nın sonunu getirmiştir. $\mathrm{Bu}$ dönemde azınlıkların ve ulusların bağımsızlığını kazanması ile Türk unsuru da artık sahneye çıkmıştır. II. Meşrutiyet'le kısmen basına özgürlük gelmiş ve fikirler daha geniş bir şekilde duyurulmaya başlanmıştır. Bu devrin önemli fikir hareketi Genç Kalemler dergisi olmuştur. Ümmet bilincinden millet

dönemlere denk gelir. Mısır'da Mehmet Ali’ye karşı destek arayışı, Kırım Savaşı, olası Rus Savaşı buna örnektir. Dolayısıyla bu gelişmeler, yani Batılılaşma hareketleri biraz da diplomatik bir gereklilik olarak ortaya çıkmıştır.

${ }^{4}$ Batılılaşma hareketinde gazetecilik faaliyetlerinin ve bu faaliyetleri yürüten aydınların önemli bir rolü vardır.

${ }^{5}$ Berkes'e göre (2017, 375-376), Abdülhamit'in din-devlet bileşimi modeliyle yürüttüğü rejim, alttan alta onun tam karşıtı laik - materyalist fikirlerin gelişmesine zemin hazırlamıştır. 
şuuruna geçişte rol oynayan Ömer Seyfettin ve bilhassa Ziya Gökalp, bu dergiyle beraber Türkçülüğün savunusunu yapmıştır (Lewis, 1998: 348). Gökalp, Türkleşmek, İslamlaşmak ve Muasırlaşmak kavramlarını Türk fikir hayatına taşımış, Osmanlının çökmekte olduğu süreçte, millî devlet yapısının milliyetçi, müslüman, tarihî değerlere bağlı olmakla beraber Batı medeniyetinin teknik ve bilimsel gelişimini almak gerekliliğini savunan bir tez ortaya atmıştır (Gökalp, 2006).

Türk modernleşmesi, Cumhuriyetin ilân edilmesiyle beraber büyük bir adım atmıştır. Mustafa Kemal Atatürk'ün "muasır medeniyetler seviyesine ulaşma" fikri, devlet politikası hâline gelerek Batılılaşma süreci hızlanmıştır. Bu dönemdeki inkılâp hareketleri, Osmanlıda yaşandığı gibi, devletin bizzat kendi eliyle gerçekleştirdiği yenilikler olduğu için "otoriter modernleşme" kapsamında gerçekleşmiştir.

Şerif Mardin, Osmanl1-Türk modernleşmesini "merkez - çevre ilişkileri" bağlamında değerlendirmiştir. Ona göre, merkez yani saray veya iktidar merkezde bulunur ve daha rafine, daha yeknesak bir kültüre sahiptir. Çevreyi oluşturan kitle, yani halk ise bu kültürden mahrum kendi geleneksel değerleri içinde yaşarlar ve merkezden çevreye doğru bir hareket söz konusudur. Osmanlı'da sarayın bu tutumu modern Türkiye'de yönetici ve bürokrat seçkinler tarafindan devşirilerek devam ettirilmiştir. Yani modernleşme sürecinde merkezin rolünde bir devamlılığın esas olduğu söylenebilir (Mardin, 2017: 272-273).

Sonuç olarak Türk modernleşmesi, devletin modernleşme politikaları neticesinde geliş̧siştir. Batı dışı bir toplum yapısına sahip olan Türk toplumunda modernleşme sürecinin başarısı gazeteci - memur - aydın kesiminin rolüne bağlıdır. Her aydın, sorgusuz sualsiz Batı kültür ve medeniyetini kabul etmemiştir. Batılılaşma vakıası, Türk aydını tarafından bir gereklilik olarak görülse de bu konuda farklı görüş ve düşünceler dile getirilmiştir.

\section{Ahmet Hamdi Tanpınar ve Aydın Kişiliği}

\section{1. "Aydın” Kavramı Üzerine}

"Aydın" kavramı, şüphesiz modernleşme sürecinin anahtar kavramlarından biridir. Zira halk nezdinde yeni fikirlerin kabul edilmesinde temsil görevi gören aydınlardır. Edward Said'e göre (2015: 28), aydın (entelektüel) "belli bir kamu için ve o kamu adına bir mesajı, görüşü, tavrı, felsefeyi ya da kanıyı temsil etme, cisimleştirme, ifade etme" yeteneğine sahip olan kişidir. 
Cemil Meriç’e göre (2016: 24) aydın, "zamanının irfanına sahip olan", ülkesinin dilini, edebiyatını ve tarihini bildiği gibi dünyadaki düşünce akımlarına da hâkim olan kişidir. "Bağımsız bir mücahit" olan aydın, dürüst, uyanık ve cesur olmasının yanı sıra kendi kafası ile olayları değerlendiren, peşin hükümlere kanmayan biri olarak toplumdaki yerini almalıdır. Meriç'in aydın değerlendirmesi, Said'in tanımıyla benzerlik göstermekle birlikte, ondan farklı olarak Bu Ülke müellifi, aydının ahlakî yönlerine de vurgu yapmıştır.

Said'e göre (2015: 56) aydın, şair, ressam veya romancı, ulusunun yaşadığ1 tarihî tecrübeyi estetik açıdan cisimleştirebilme işini, geniş bir insanî alana yayarak meselenin evrensel boyuta ulaşabilmesini sağlayabilmelidir. Ayrıca aydın kişilik, gerçek anlamda olmasa da bir "sürgün" olmalıdır. Alışılagelmiş olanı veya otoritenin sunduğunu kabul etmemeli, yenilikçi ve gezgin olmalıdır. Böylece bir "sürgün" gibi düşünerek olaylara farklı bir gözle bakmayı başarabilir (Said, 2015: 73-74).

Ayşe Ülkü Oğuzhan Börekçi, aydını, bir başka deyişle entelektüeli, "eleştiren, sorgulayan, özgürleştirme için çaba harcayan" kişi olarak tanımlamıştır. Aydının bu özellikleri, aynı zamanda diğer meslek gruplarına kıyasla onun ayırt edici nitelikleridir. Batı dışı toplumlarda ise aydın, genellikle merkezde yer aldığ 1 için söz konusu nitelikleri tam anlamıyla taşımaktan uzaktır. $\mathrm{Bu}$ aydınlar, daha çok modernleşme politikalarının belirlediği çizgide hareket eder (Börekçi, 2017: 406).

Türk aydının genel niteliği, devletle uyum içinde olması, yani merkezde yer almasıdır. Bu özellik Cumhuriyet devrinde de değişmemiştir. Bununla birlikte çok partili hayata geçiş sürecinde Türk aydınının demokrasi talepleri artmış, daha muhalif bir yapı içine girmiştir. Tek Parti devrinde "öğretmen-aydın", "memmur-münevver" tipi hâkimken, çok partili hayatta daha bağımsız ve muhalif bir aydın tipi doğmuştur (Börekçi, 2014: 74-75).

Sonuç olarak bu makalenin ana konusunu oluşturan Ahmet Hamdi Tanpınar ve eserlerinde temsil edilen aydın tipi, batı dışı toplumların modernleşme sürecindeki aydınların işlevlerini yansıtır. Fakat Tanpınar'ın kendisi, bu aydın tipini yansıtmaz; o daha çok modernleşmenin sancılarını tespit ve tahlil eden, "sağ" veya "sol" ideolojilerin dar kalıpları arasına sıkışmadan, Meriç'in deyimiyle "bağımsız bir aydın" kimliğini temsil eder. Nitekim Tanpınar, toplumunun tarihî sürecini estetik biçimde temsil etme vazifesini üstlenerek yukarıda tanımlanan aydının -entelektüelinayırt edici niteliğini taşır. 


\subsection{Ahmet Hamdi Tanpınar'ın Kısa Hayat Hikâyesi}

Ahmet Hamdi Tanpınar, 23 Haziran 1901'de İstanbul Şehzadebaşı'nda Hüseyin Fikri Efendi ve Nesibe Bahriye Hanım'ın çocuğu olarak dünyaya geldi. Babasının memuriyeti sebebiyle çocukluğu muhtelif şehirlerde, Ergani, Sinop, Siirt, Kerkük ve Antalya'da geçmiştir. Kerkük, Vefa ve Antalya Rüştiyelerinde okuyan Tanpınar, 1918 yılında Baytar Mektebi'ne kayıt yaptırmış, 1 yıl sonra Edebiyat Fakültesi'ne, önce tarih, sonra felsefe bölümüne geçmiştir. Fakat Yahya Kemal'in edebiyat şubesinde ders vereceğini duyuca kaydını bu şubeye aldırdı ve 1923 yılında buradan mezun olarak Erzurum, Konya, Ankara, ve Kadıköy liselerinde öğretmenlik vazifesine tayin edildi. Daha sonra Güzel Sanatlar Akademi'sinde estetik mitoloji dersleri veren Tanpınar, 1939 y1lında İstanbul Üniversitesi Edebiyat Fakültesi bünyesinde kurulan 19. Asır Türk Edebiyatı kürsüsüne, dönemin Maarif Vekili Hasan Ali Yücel tarafindan edebiyat profesörü olarak getirildi. 1943-46 arası Maraş milletvekilliği yapmış ve 1949 'da tekrar Fakülteye dönmüştür. Son yıllarında yaşadığı muhtelif sağlık sorunları sonrası 24 Ocak 1962 tarihinde hayata gözlerini yumdu (Okay, 2010: 567).

Ahmet Hamdi Tanpınar'ın edebî ve fikrî gelişiminde Yahya Kemal'in önemli tesiri vardır. Şiirin ve millî değerlerin özünü ondan öğrenen Tanpınar, dil güzelliği, mükemmellik fikri ve bilhassa tarih zevkinin, tarihin fikrî gelişime bir kaynak teşkil etmesi konularında Yahya Kemal'den etkilenmiş ve bunları kendi eserlerine de taşımıştır. Tanpınar, ayrıca Yahya Kemal'in Dergâh mecmuasında şiirlerini neşretme firsatı bulmuştur (Akün, 1962: 5-6).

Tanpınar, Türk Edebiyatı kadar Batı edebiyatını da okumuştur. Özellikle Valery, Gide ve Proust'un eserleri, yazarın edebî ve estetik gelişiminde rol oynamıştır. Tanpınar'ın estetiği rûya, mûsiki ve şuurlu çalışma fikrinden mürekkeptir. Varlık, Kültür Haftası, Ağaç, Oluş gibi mecmualarda yayımlanan şiirleri, onu şiir alanında özel bir yere koymuştur. Şiirin dışında Güzel Sanatlar Akademisi'ndeki öğretmenliği nedeniyle musiki, plastik sanatlar ve resim hususunda da kendini geliştirmiştir. Tanpınar'ın eserlerinde rüya kavramı kadar, resmin de, tasvirlerinin güzelliği sebebiyle büyük payı vardır (Akün, 1962: 7-8).

Tanpınar, şiir, deneme, roman, hikâye gibi türlerde eserler vermiştir. Mahur Beste, Huzur, Saatleri Ayarlama Enstitüsü, Sahnenin Dışındakiler roman türünde, Abdullah Efendi'nin Rüyalarl, hikâye türünde, Bütün Şiirleri, şiirde, Beş Şehir deneme türünde en önemli yapıtları arasındadır. Bunların dışında Tanpınar'ın Edebiyat Fakültesi'nde profesörlüğe 
getirilmesinin akabinde hazırladığı 19. Asır Türk Edebiyatı Tarihi eseri de ilmî ve akademik bir kitap olarak kültür hayatında önemli bir yer işgal eder.

\subsection{Ahmet Hamdi Tanpınar'ın Aydın Kişiliği}

Ahmet Hamdi Tanpınar, kısa hayat hikâyesinden de anlaşılacağı üzere Cumhuriyet devrinin önemli aydınlarından biridir. Üniversite hocalığının yanı sıra eserleri ve eserlerinde işlediği konular bunun en belirgin göstergesidir. Yüksek bir edebî dile sahip olan Tanpınar, musiki, resim, edebiyat ve hatta ilmî nitelikteki eserleriyle Türk kültür hayatında müstesna bir köşeye kurulmuştur.

Uçman ve İnci, felsefeye ilgi duyan, klâsik Türk ve Batı musikisini, divan şiirini iyi bilen Tanpınar'ın, yaşadığı devirdeki aydınlardan sosyal meseleleri farklı bir bakış açısıyla ele almasıyla ayrılan bir düşünce adamı olmasına dikkat çekmiştir (Kaplan, 2008: 12).

“Bir düşünce adamı olarak Tanpınar'ın önemi, Türk kültürünün geçmişi hakkında ileri sürdüğ̈̈ görüşlerin orijinalliği kadar, bunların, ortaya çıktı̆̆ı dönemin şartları bakımından da son derece dikkati çekici olmasından gelmektedir. Tanpınar, gerek Beş Şehir, gerekse ölümünden sonra yayımlanan Yaşadığım Gibi'deki yazılarında Türk kültürünün tarihî gelişme çizgisinden uzaklaştırıldı̆̆g, Türk toplumunun geleceğini belirleyecek hayat tarzının ancak "geçmiş"ten kopmakla mükün olabileceği görüşünün geçerli olduğu bir dönemde bu kopuşun ortaya çıkardığ ve çıkarabileceği çeşitli meselelere rahatça, ama başkaları gibi kavga etmeden yaklaşabilme yürekliliğini de göstermiş bir aydındır."

Tanpınar, yalnızca Cumhuriyet değerlerini değil aynı zamanda Osmanlı kültür birikimini de romana taşıyan, "destekleyici veya eleştirel” olmaktan ziyade anlamak adına çalışan bir aydındır. Tanpınar, eserlerini bu noktadan hareketle Batılılaşma meselesini daha farklı bir bakış açısıyla irdelemeye çalışmıştır (Gündüz, 2002: 19).

Tanpınar, ideolojik veya fikrî anlamda yaşadığı dönem içinde herhangi bir kategori içerisinde konumlandırılamadğ 1 için "tereddüt eden adam" olarak değerlendirilmiştir. Bu hususta yazar, "Solcu muyum sağcı miyım?" sorusuna "Ben sadece hakem vaziyetindeyim. Ben sadece eserim, şahsen yapabileceğim şeyi yapmak istiyorum. Ben maruz ve müşahidim” cevabını verir (Berksoy'dan aktaran Özgür, 2010: 31).

Tanpınar, eserlerine yaşadığı devrin aydınları ve eleştirmenleri tarafından yeterince alaka gösterilmemesine içerler ve bu yaşadığını bir "sükût suikasti" olarak değerlendirir. Türkiye'de sağ ve solun yapıları gereği kendisindeki Türkiye tasavvurunu anlayamadığını belirten yazar 
kendisinin "dünya içinde, ileriye açık, mâzi ile hesabını gören bir Türkiye'nin peşinde" olduğunu vurgulamıştır (Kaplan, 2008: 14-15).

Tanpınar, Cumhuriyet döneminde yaratılmaya çalışılan yeni millî kimlik yapısının "geçmişi reddederek" veya "yeni olanı kabul etmeyerek" değil her ikisini de uygun zeminlerde kullanarak ortaya çıkarılacağ kanaatindedir. Bu hususta Gündüz'ün şu tespitleri önemlidir (Gündüz, 2002: 20):

“Tanpınar'da söz konusu yeni ulusal kimlik geleneğin birikiminden beslenerek yaratılacaktır. Tanpınar Batının mevcudiyetini, bilim ve teknik alanındaki başarılarını kabul eder. Bu tarz bir etkiyi de yadsımaz ama bu durum kendi tarihimizin toptan iptalini gerekli kılmamalıdır. Tanpınar'da yeni kimlik Doğu ve Batının ortasından yaratılacaktır. Tanpınar'ın romanlarında kurguladı̆̆ tipler ihmâl etmediği tarihin, kültürün ve geleneğin insanlarıdır."

Sonuç olarak Tanpınar'ın aydın kişiliği, modernleşmenin karşısında olmamakla beraber tarihî, millî ve manevî değerleri ihtiva eden bir kültür birikiminin önemi üzerinde durmaktadır. $\mathrm{Bu}$ yüzden Osmanlı'y1 reddetmez, en azından Osmanlı'nın sanat ve estetik zevkini sahiplenir. Tanpınar'ın zaman kavramına göre Türk tarihini ve kültürünü belli bir tasnife ayırmak doğru değildir. Eğer geçmişin kültürel değerleri bugün de bir anlam ifade ediyorsa bunu atmak yerine yeni bir terkip ile zenginleştirmek gerekir. Öte yandan modernleşmenin getirdikleri, belli değerleri yıkmak üzerine kurulu ise bu da bir tenkid malzemesi olmayı hak eder. İşte Tanpınar'ın aydın kişiliği bu düşünceler temelinde oluşmuştur.

Buradan hareketle Tanpınar'ın aydın kişiliğinin, modernleşen toplumlarda halktan kopuk veya kültürel değerleri göz ardı eden ve merkezci modernleşme politikasının bir uygulayıcısı olan aydın tipinden uzak olduğu söylenebilir. Tanpınar, eserlerinde bu aydın tipini tenkit eder, hicveder. Bu yüzden yalnızca söz konusu aydın tipinin varlığını kabul eder, niteliklerini tespit eder. Fakat hiçbir zaman onu ideal bir aydın tipi olarak sunmaz. Neticede Tanpınar, modernleşme ve kültürel birikimi bir arada götürmeyi teklif ederek orta noktada buluşmayı daha doğru bir yol olarak görür.

\section{Ahmet Hamdi Tanpınar ve Eserlerinde Temsil Edilen Aydın Kimliğ i}

Ahmet Hamdi Tanpınar'ın muhtelif eserlerinde aydın kimliği temsil edilmiştir. Tanpınar'ın aydın tipi, edebî eserlerindeki karakterler veya doğrudan kendi düşüncelerini dile getirdiği eserler vasıtasıyla ortaya çıkmıştır. Edebî eserlerinde ideal gibi sunulan fakat aslında tenkit edilen 
bir aydın kimliğinin yanı sıra bizzat Tanpınar'ın kendi aydın tipine uygun bir aydın kimliği de vardır. Bunun yanı sıra, mesela Beş Şehir isimli deneme eserinde olduğu gibi bizzat kendi düşüncelerini ifade etmek suretiyle ortaya çıkan bir aydın kimliği vardır.

Ahmet Hamdi Tanpınar, görüş, düşünce ve kanaatleriyle, muhtelif eserlerinin ihtivasıyla "terkibi arayan" bir aydın tipi ortaya koymaktadır. Bu tip, Tanpınar'ın bizzat kendisidir. Terkibi arayan aydın olarak Ahmet Hamdi Tanpınar, siyasî, sosyal ve kültürel konularda muayyen bir ideolojinin temsilcisi gibi değil de Meriç'in "bağımsız aydın" olarak tanımladığı bir fikir adamıdır. Bu, geçmişle barışık, kültürel değerleri muhafaza eden, Batılılaşma vakıasına karşı olmayan bilâkis Batının getirdiği metod ve düşünceleri benimseyen fakat aynı zamanda Şarklı değerleri de bir zenginlik addeden bir aydın tipidir.

Bu çalışmada Tanpınar'ın eserlerinde modern kurumların eleştirisi, şark değerlerinin benimsenmesi, aydınların temsili gibi konular yeni aydın tipini oluşturan başlıklar olarak tespit edilmiştir. Söz konusu başlıklar Tanpınar'ın eserlerinin yanı sıra eserleri hakkındaki çalışmalardan da istifade edilerek incelenmiştir.

\subsection{Modern Kurumların Eleştirisi}

Tanpınar'ın Saatleri Ayarlama Enstitüsü ${ }^{6}$ isimli romanı, Cumhuriyet döneminin Batılılaşma politikasını tenkid eden hiciv yüklü bir romandır. Başkarakteri Hayri İrdal'ın başından geçen maceraların anlatıldığı romanda, faaliyetleriyle oldukça garip bir kuruluş olan SAE'nin nasıl ve neden kurulduğunun hikâyesi anlatılmaktadır. Özellikle kitabın son bölümü, aynı zamanda Cumhuriyet devrinin modern kurumlarına ve bürokrasi yapısına bir eleştiridir. Zira bu kadar garip bir kuruluşun bile tıpkı bazı modern kurumlar gibi gerekli olmadığı halde alanında uzmanlaşması, pek çok şube açarak büyümeye çalışması değişen kültür değerlerinin de bir yansımasıdır (Tanpınar, 2015a).

Tanpınar'ın zaman kavramına verdiği önemi belirten fakat SAE'de alışıldık zaman mefhumunun dışında "donmuş kalmış", "dışına çıkılamayan" bir zaman algısının belirdiğini ifade eden Mehmet Kaplan, bu romanı Türk toplum hayatının "gizli noktalarına kuvvetli bir projektör" şeklinde değerlendirmiştir. Kitabın özellikle son kısmı, yani Cumhuriyet devrinin modern fakat anlaşılamaz ve gülünç bir metoda sahip olan katı

\footnotetext{
${ }^{6}$ Makalenin bu bölümünden sonra Saatleri Ayarlama Enstitüsü, SAE (kelimelerin baş harfleri) ile anılacaktır.
} 
sistemine bir eleştiri olan bölümü, Kaplan'a göre romanın anlattığ 1 "abes" hayat süren kişilerin en güçlü tezahürüdür (Kaplan, 2008: 109-111).

Ahmet Kutsi Tecer, Tanpınar'ın ölümünden sonra SAE hakkında yazdı̆̆ 1 bir yazıda, romanın Türk edebiyatının geleceği için yeni ufuklar getireceği umudunu belirtir. Romanın özü Tecer'e göre, Hayri İrdal isminde tuhaf bir karakter üzerinden memleketin "sahte sosyal değerler, sahte ekonomik değerler üzerine kurulan" kurumlarının bir eleştirisidir. Fakat romandaki eleştiri Halit Ayarcı ismindeki karakterin fikri üzerine kurulan ancak yalan ile kendini sürdürmeye çalş̧an böyle bir kurumun hangi tiplerle yürütebileceğini göstermek suretiyle ortaya konmaktadır. Bu tiplerin toplum içindeki yerini gösterdiği için SAE, Tecer'e göre aynı zamanda psiko-sosyal ve çapraşık bir olaydır (Tecer, 1963: 2).

Berna Moran, SAE'yi bir tür hiciv yöntemiyle kaleme alınmış bir eser olarak yorumlamıştır. Geleneksel değerlere ters düşen davranışları sergilemek için kullanılan hiciv, romanda da muhtelif bozukluklara -gurur, ikiyüzlülük, bencillik, para hırsı vs.- işaret etmek için kullanılmıştır. Moran'a göre Tanpınar, ne iş göreceği tam olarak belirlenmeden kurulan SAE ile politikacılar, köksüz devrimler, bürokrasi, Batı taklitçiliği gibi kişi, kurum ve faaliyetleri hicvî yönden tenkid etme olanağı bulmuştur. Halit Ayarcı karakteri, yeniye olan düşkünlüğü ile Cumhuriyet'in Batıdan kopya ederek modernleşme zihniyetini eleştirmiştir (Moran, 2008: 262267). Ahmet Hamdi Tanpınar'ın geçmiş değerler ile Batının terkibinin ideal olarak anlamlandırdığı değişim meselesi göz önüne alındığında "sırf yenidir" diye bir şeye sarılmanın getireceği buhran bu eserinde estetik bir biçimde ifade edilmiştir.

\section{2. Şark Değerlerinin Benimsenmesi/Hatırlanması}

Ahmet Hamdi Tanpınar, muhtelif eserlerinde Şarka ait özellikleri ön plana çıkartır. Kuşkusuz bunun en önemli sebebi Osmanlı mirası ile dinî değerlerin topluma nüfuz etmiş olmasıdır. Yazar, hemen her eserinde bu hususu bir yönüyle de olsa belirtmiştir. Mahur Beste, Şarklı değerlerin kültürün önemli bir unsuru olarak sunulduğu önemli bir romandır.

Mahur Beste'de sarayın emri ile kendisinden daha kültürlü bir kadın olan Atiye hanım ile evlenen Behçet Bey'in babası İsmail Molla, romanda Şarkın hususiliğini yansıtan bir karakter olarak ön plana çıkmıştır. İsmail Molla, sert mizaçlı olduğu kadar sanattan ve bilhassa musikiden anlayan renkli bir kişiliğe sahiptir. Oğlu Behçet'in kendisi gibi olmayışına üzülür. Hatta bu yüzden gelini ile daha iyi anlaşır. İsmail Molla'nın arkadaşı Sabri Hoca ise, Suavi Vakasına karışmış, ailesi tarafından unutulmuş ihtilal yanlısı bir karakterdir. Sabri Hoca, değişimden yana olmakla beraber, değişimi bir "medeniyet veya kültür" değişimi olarak değil; Abdüülhamid 698 
rejiminin değişimi ve beraberinde yıkık, viran Şarkın yeniden anlam kazanması yönündeki bir değişim olarak algılar. Zira ona göre "Şark ölmüştür". Fakat Sabri Hoca, bu düşüncesini izah ederken Şarkın yüksek değerlerinden de bahseder. Şark'1, İsmail Molla'nın bir zamanlar büyük bir yangında kül olan teyzesinin konağına benzetir. Bu konakta bulunan ceviz bir sandık vardı ve Molla onu her açtığında yeni ve güzel bir eşya ile karşılaşırdı. Sabri Hoca, bu hususu da Şark'ın özelliği olarak gösterir (Tanpınar, 2016: 94):

"İşte medeniyet dediğin bu konağa benzer. Evvelâ o sandiğın mucizesi vardl. Yani rahmetli büyük annenin hoşuna gidecek şeyleri sen farkına varmadan hazırlayan sevgisi. Bu, o medeniyetin yaratıcı tarafi vardir ve hakikaten bir mucizeye benzerdi. Her şey adeta hazır gibi bir aranmadan bulunur. Her tesadüf, her adım bir mevsim gibi yüklü ve zengindi. Hiçbir arıza bu cömert feyzi tüketmez. Bağdat bitince Kurtuba başlar. O bitince Bursa, Istanbul doğar. En büyük sanat adamından en basit işçisine kadar her kafa, her kol sonuna kadar velûttur."

İsmail Molla, Sabri Hoca gibi Şark'a umutsuz gözlerle bakmaz. Şarkın aslında halk tarafindan yapılan bir inanç, manâ ve hayat şekli olduğunu düşünür. Türk kültürünün Müslümanlık inancı ile yoğrulmasından kendine has bir terkip oluşturur. Bu terkibin özünü ise bu topraklar ve onun üstündeki cemiyet oluşturur. Romanda Sabri Hoca'nın "Şark öldü" ifadesine cevaben İsmail Molla şark değerlerinin kültürle olan ilişkisini şöyle anlatır:

“...Bu müslümanlı̆ğn benim de herkes gibi inandlğım akîdeleri vardır. Fakat onların arkasında kendilerini aydınlatan, mânalarını yapan bütün bir hayat vardir, halk vardır. Asll sihrini o yapar. O ne medreseden, ne tekkeden, ne şeyhülislam kapısindan, ne kazasker konağından gelir; halkın hayatından doğmuştur. Onun içindir ki o hayatın emrindedir, ruhaniyeti onunla beraber yürür, içine frenk icadı bile girer; fakat manzarası bizim kalır. " (Tanpinar, 2016: 96)

Tanpınar, Beş Şehir'de de şarkın kültürümüzde oynadığı role dikkat çekmiştir. Mimarî eserleri, musikisi, hayata, kâinata ve ölüme bakış tarzı hep Şark'ın ve aslında onun da altında yatan İslâm'ın kültür ile terkibi ile oluşmuştur. Tanpınar'ın bu eserinde ele aldığ İstanbul, Bursa, Erzurum, Konya ve Ankara şehirleri, belli bir tarihî birikimin neticesi olarak ortaya çıkmıştır ki bu birikimin temelinde yatan Türk-İslâm kültürü, yani Şark, kayda değer bir önem arz etmektedir. Yazar, her biri kendine has özellikleri ihtiva eden bu şehirlerin manzarasını geçmişe ait unsurlarla beraber ele alır. 
Sonuçta Tanpınar'a göre Şark benimsenmeli ve hatırlanmalıdır. Bu, kültür ve medeniyetin bir zenginliğidir. Bu zenginliğe yüz çevirmek yerine onu anlamak, onu "yeni”" ile dokuyarak daha başka bir hâle getirmek gerekir.

\subsection{Aydının Temsili}

Tanpınar, muhtelif eserlerinde Türk aydınının rolünü ve meseleler karşısında takındığı tavrı konu edinmiştir. Modernleşme karşısında daha mutedil bir aydın kimliği temsil edilir. Modernleşmenin dönüştürdüğü unsurlar, niteliğine göre tenkid veya kabul edilir. Genellikle toplumun manevî yapısına uygun olmayan değişmeler Tanpınar'ın aydın algısında tenkid edilir. Bununla beraber taşrayı temsil eden Anadolu ile şehri veya merkezi temsil eden İstanbul arasındaki farklar da romanlarda işlenmiştir. Sahnenin Dişındakiler ve Huzur romanları yazarın aydınları yansıtma firsatı bulduğu eserleridir.

Mahur Beste, Sahnenin Dışındakiler ve Huzur romanları, belli karakterleri müşterek olan ve birbirlerinin devamı sayılabilecek eserlerdir. Mahur Beste'nin Atiye Hanım'ının kuzeninin çocuğu olan Cemal, Sahnenin Dışındakiler romanında başkarakterdir. Muhafazakâr bir mahalle kültüründe yetişen Cemal, Millî Mücadele yıllarında "Sahnenin Dışı" olan İstanbul'da ikâmet etmektedir. İlk bölümde çocukluk aşkı Sabiha ile olan hatıralarını anlatan Cemal, ikinci bölümde babası gibi hovarda ve ayyaş olan bir kişiyle evlenmiş olan sevdiğinin izini bulmaya çalışır. Hâdiseler romandaki hemen her karakterin Sabiha ile bağlantısı olduğu izlenimini Cemal'e verir yahut psikolojik açıdan Cemal bunun böyle olduğunu zanneder. Bu sırada Cemal işgal altındaki İstanbul'un kendi birliği için ve Anadolu ile temasını kurabilmesi için bazı uğraşlar vermektedir. Tanpınar, romanda okura Anadolu-İstanbul farklılığını ima etmeye çalışır. Çocukluğunda babasının memuriyeti dolayısıyla Anadolu'da bir süre vakit geçiren Cemal, Anadolu insanının vaziyetini bilmektedir. "Anadolu acıdır" ve İstanbul'un modern hayatını yaşayanlardan daha fazla millî ve manevî bir duyarlılığa sahiptir (Tanpınar, 2015b). ${ }^{7}$

Selim İleri’ye göre Sahnenin Dışındakiler, kavganın dışında kalan, Anadolu'daki millî mücadelenin sıcak temasından uzaktakileri anlatan bir romandır. Roman Tanpınar'ın “gerçek aydın, gerçek kavga adamı" olamayanlara karşı yönelttiği bir suçlamadır (İleri, 2008: 221).

Fethi Naci, Sahnenin Dışındakiler'de toplumda yeni insan tiplerinin ortaya çıktığını, modernleşmenin dönüştürdüğü bireylere dikkat çekmiştir.

7 Yazar, kitabında Anadolu ve İstanbul arasındaki bu farkın türkülerin muhtevasından da anlaşılacağını belirtmiştir. 
Süleyman Bey, Behçet Bey, Kudret Bey ve Nâsır Paşa gibi karakterler, Osmanlı gibi çökmüşlerdir. Oysa İbrahim Bey ve Hasan Bey modern liberal tesirle birlikte ticaret burjuvazisini temsil eden bireyler olarak sunulur (Naci, 2008: 236). Sonuçta bu eserde modernleşmenin insan ve toplumu değiştirme gücüne ve aydınların halktan ayrılan yönüne vurgu yapılmıştır.

Huzur romanında Tanpınar, Mümtaz karakteriyle yeni bir Türk aydını tipi oluşturmuştur. Uzun bir ruhî macera sonunda Mümtaz, bu aydın tipine kavuşmuştur. Geçmişin değerlerini kendini gerçekleştirmek adına benimseyen, bugünü ve yaşadığı toplumu dikkate almayarak daha bireyci olan Mümtaz, zamanla romanın bir diğer karakteri İhsan'a, dolayısıyla Tanpınar'ın fikrî çizgisine yaklaşmıştır. Mümtaz'ın son merhalede ulaştığı düşünce yapısı, bir başka deyişle Yeni Türk aydınının özellikleri şöyledir: yeni Türkiye'yi kurabilmek için vatan ve millet sevgisiyle gücü imandan almanın gerekliliği kadar meseleler akılcı bir metodla çözülmelidir. İnsan, yaşadığ 1 topluma hüviyetini kazandıran bir "çimento" olmalıdır. Birey, bu doğrultuda yüklendiği sorumluluk kadar değer kazanır. Sonuç olarak Mümtaz, "huzuru" kendi içinde kavramış ve geçmişten aldığı mirası, bugünü ve geleceği inşa edecek yeni terkiplerle, madde ve ruhun ahenkli bir bütünüyle oluşturulabileceği kanaatine varmıştır. Doğu - Batı çatışmasının çözümü ancak böyle bir şuurla işleyen aydın tipinin temsil edilişiyle mümkün olur (Kantarcıoğlu, 2008).

Sonuç olarak Tanpınar'ın eserlerinde temsil ettiği aydın tipi modern devletin "ideologları" değildir; aksine geçmiş ile gelecek arasında veya eski - yeni, Doğu - Batı arasında ahenkli bir bağı inşa eden kişilerdir. Bu yüzden gerektiğinde modern kişi, kurum veya faaliyetler eleştirilir. Medeniyet, manevî kıymetler olarak alındığından bunun karşısında olan modern dönüşümler tartışmaya açılır. Bununla beraber Tanpınar'ın durduğu kesin bir nokta yoktur. O doğru ve ideal olanı "arayan" bir aydın resmi tasvir etmiştir.

\subsection{Yeni Bir Terkibin Peşinde}

Tanzimat devrinden itibaren modernleşme / Batıl1laşma yoluna giren Türkiye iktisadî, içtimaî ve kültürel değişimler yaşamıştır. Bunların bir kısmı halkın ve bir kısım aydınların tepkisini çekmiştir. Modernliğin getirdiği düzen, özellikle manevî konularda bir bozulmaya yol açtı̆ğ endişesini doğurmuştur. Öte yandan liberalizm de geleneksel iktisadî ilişkilerin yerine geçmiş ve Giddens'ın belirttiği zaman - mekân olgusunu ortadan kaldıran hıza ve kâra dönük bir ekonomi tarzını getirmiştir. Bu meseleler Genç Osmanlılardan Cumhuriyet aydınlarına kadar farklı bakış açılarından ele alınmıştır. 
Tanpınar, bu meselelerin tam ortasında durmakadır. Batılılaşma ile ilgili müşahhas bir görüşünden bahsetmek zordur. Daha doğrusu o, "yeni bir terkib"in peşindedir. Bu terkipte estetik kayg1 önemli bir yer tutar. Şiirlerinde hece veznini tercih etmesi, nesirde modern edebiyatın özelliklerini benimsemesi onun Batı ile temasını gösterir. Fakat Yahya Kemal'in de tesiriyle Türk İslâm kültür ve medeniyetinin tarihî mirasını sahiplenerek Şark ile bağını da muhafaza eder. Ondaki Doğu algısı ideolojik olmaktan ziyade estetik ve kültüreldir.

Beş Şehir ve Huzur'da söz konusu yeni terkibin yansımalarını görmek mümkündür. Deneme türündeki Beş Şehir, Türk kültür ve medeniyetinin tezahürlerini ihtiva eden ve Türk tarihinde dönüm noktaları olmayı başarmış beş güzide Türk şehrinin -Ankara, Erzurum, Konya, Bursa, İstanbul-, estetik açıdan ele alınmasıyla ortaya çıkmıştır. Tanpınar, eserinde tabiri caizse "rüya" görmektedir, yani rüya görür gibi gördüklerini hülyalı bir eda ile anlatır. $\mathrm{Bu}$ onun zaman mefhumunun niteliği ile de yakından ilişkilidir. Zira Tanpınar, geçmiş zamanın içinde yaşar ve onu bugünde arar. Bulduklarını ve bulamadıklarını kendine has üslubu ile aktarır. Özlem içindedir, çünkü gördüğü rüya veya yaşadığ geçmiş zamanın mekânlarındaki yaşanmışlıklar, ona göre güzel şeylerdir (Tanpınar, 2015c).

Tanpınar, Şarklı değerleri Evliya Çelebi'den, engin tarih bilgisinden ve gezip gördüğü şehirlerin yapılarından çıkarır. Ankara'da Hacı Bayram-1 Veli, Erzurum'da İbrahim Hakkı, Konya'da Mevlâna, Bursa'da Emir Sultan, İstanbul'da Mimar Sinan, Yahya Kemal ve niceleri bu medeniyetin manevî inşasını yapmışlardır. Tanpınar'a göre ataların "yapıcılığı" manevî bir hüviyet taşır. Bursa kısmında bunu şu şekilde anlatır:

"Cetlerimiz inşa etmiyor, ibadet ediyorlard. Maddeye geçmesini ısrarla istedikleri bir ruh ve imanlart vardl. Taş, ellerinde canlaniyor bir ruh parçası kesiliyordu. Duvar, kubbe, kemer, mihrap, çini, hepsi Yeşil'de dua eder, Muradiye'de düşünür ve Ylldırım'da harekete hazır, göklerin derinliğine susamış bir kartal hamlesiyle ovanın üstünde bekler. Hepsinde tek bir ruh terennüm eder." (Tanpınar, 2015c, s.110)

Tanpınar, Huzur romanında aydın kimliğini Mümtaz'ın kuzeni İhsan karakteri üzerinden ortaya koymuştur. Romanda İhsan, Doğu Batı meselesine kafa yoran, onun çıkmazlarını çözüme kavuşturmaya çalışan, kısacası "yeni bir terkip" oluşturmaya çalışan aydını temsil eder. Bayramoğlu'na göre (2007: 70-73) İhsan karakteri Huzur'a fikir romanı hüviyetini kazandırmıştır.

Bayramoğlu'nun da belirtttiği gibi Mümtaz'ın Batılılaşma karşısında toplumun geçmiş değerlerinden koptuğu fikrine karş1lık olarak İhsan, 
Şarklıya ait öz zenginliğimizin farkında olamadığımız için bu meselenin doğduğu tespitine varmış ve konuyu şu ifadelerle aydınlatmıştır (Tanpınar, 2014: 270):

“- Güçlük var. Fakat imkânsız değil. Biz şimdi bir aksülamel devrinde yaşıyoruz. Kendimizi sevmiyoruz. Kafamız bir yığın mukayeselerle dolu; Dede'yi Wagner olmadığ için, Yunus'u Verlaine, Bakî'yi Goethe ve Gide yapamadı̆̆ımız için beğenmiyoruz. Uçsuz bucaksız Asya'nın o kadar zenginliği içinde, dünyanın en iyi giyinmiş milleti olduğumuz hâlde çırllçıplak yaşlyoruz. Coğrafya, kültür, her şey bizden yeni bir terkip bekliyor; Biz misyonlarımızın farkında değiliz. Başka milletlerin tecrübesini yaşamaya çalışıyoruz."

Neticede Tanpınar, gerek kendi fikirleri ve gerekse romanlarında yer verdiği karakterler vasıtasıyla bir terkip oluşturmaya çalışmıştır. Bu terkip, Türk toplumunun Batı toplumundan farklı olduğu için Batılılaşma sürecinin de farklı olması gerektiğine yönelik bir ima taşır. Burada, Mardin'in belirttiği merkez - çevre ilişkileri çerçevesinde otoriter bir modernleşmenin manevî ve kültürel dokuyu bozacağı endişesi görülür. $\mathrm{Bu}$ yüzden farklı gelişim çizgilerinde olan Türk (veya Doğu) ve Batı toplumlarının modernlik algıları ve onu benimseyiş biçimleri de farklı olur.

\section{Sonuç}

Batı dışı toplumlar için modernleşme, bir yandan gelişme için gerekli bir hamle iken bir yandan da toplumun manevî değerlerini dönüştürücü bir tesire sahiptir. Zira modernleşmenin dinamiklerini kendi içinde yaşamayan bir toplum, onun getireceği yeniliklere hazır olamaz. Türk toplumunun modernleşme sürecinde de böyle bir durum söz konusudur. Türkiye, 19. Yüzyılın başlarından itibaren bu meselenin merkezinde bulunmaktadır. Toplumun düşüncelerini temsil eden gazeteci, bilim adam1, sanatç1 kimlikleriyle aydınlar modernleşme veya Batılılaşma sürecini çeşitli bakış açılarıyla ele almışlardır.

Tanpınar, eserlerinde Batılılaşmanın getirdiği muhtelif buhranları gösterse de tam anlamıyla Şarklı değerlerin hüküm sürmesi gerektiği fikrinde de değildir. Aslında Tanpınar'ın ana eleştiri noktası "otoriter modernleşme" politikası ile manevî değerlerin yok sayılması, asırlardır biriktirilen kültürel değerlerin bir kenara itilmesine yöneliktir. Bu yüzden manevî kültür unsurlarına sahip çıkılması gerektiği düşüncesindedir. Tanpınar'ın bu düşüncesi, otoriter modernleşmenin getirdiği dönüşüme yönelik bir itirazın yansıması olarak da değerlendirilebilir. Nitekim bu itiraz, onu söz konusu millî ve manevî kültür unsurlarına götürmüştür. Eserlerinde ve 
düşüncelerinde bu unsurlara çok defa rastlanması Tanpınar'ın fikrî hayatını göstermesi bakımından da önem arz etmektedir.

Tanpınar, madde ile mana arasında bağ kurmayı başarmış bir aydındır. Ufkunu maziye açarak oradan da birtakım değerlerin farkına varmıştır. Mesela musikide Itri ve Dede Efendi'yi sahiplenerek, bu tür şahsiyetleri kendi kültür ve medeniyetimizin birer tezahürleri olarak değerlendirmiştir. Zira Batının değerlerinin benimsenemediği hususlarda halka kötü gözle bakmanın anlamı yoktur (Gündüz, 2002: 28).

Tanpınar'ı diğer aydınlardan ayıran en önemli fark ise bir fikrin kalıpları içinde sıkışmamış olması ve düşüncelerini Said'in aydın tanımında olduğu gibi şiirsel bir estetik içinde vermeyi başarmış olmasıdır. Bu yüzden yüksek kültür seviyesi gerektiren eserler kaleme almıştır.

Sonuç olarak Tanpınar, modernleşmeye bağımsız bir noktadan bakarak Doğu ile Batı arasında ahenkli bir bütünlüğü sağlamaya çalışmış, millî ve manevî değerlerin yok sayılamayacağı yeni bir terkibin peşinden gitmiş ve eserlerinde bu düşünceyi yansıtmıştır. Bu yüzden modernleşen toplumların aydınlarından farklı olarak merkezde yer almamış, çevreyi modernleştirici bir rol üstlenmemiştir. Bunu en azından modernleşme politikalarının işaret ettiği şekilde yapmamış, çevreyi -halkı- olduğu gibi kabul edip anlamaya çalışmış, onun sahip olduğu kültürel değerlere ve birikime modernleşme yenileşme- içinde özel bir yer ayırmanın yolunu tutmuştur.

\section{Kaynaklar}

Akün, Ö. F. (31 Aralık 1962). Ahmet Hamdi Tanpınar. Türk Dili ve Edebiyatt, 12, 1-32.

Atiker, E. (1998). Modernizm ve Kitle Toplumu. Ankara: Vadi Yayınları.

Bayramoğlu, Z. (2007). Huzursuz Huzur ve Tekinsiz Saatler. İstanbul: Yapı Kredi Yayınları.

Berkes, N. (2017). Türkiye'de Çağdaşlaşma. İstanbul: Yap1 Kredi Yayınları.

Börekçi, Ü. A. (2014). Muhalif Aydın: Romanlar Üzerinden Zihniyet Okumast. Ankara: İmge Kitabevi.

Börekçi, Ü. A. (2017). Entelektüelin Toplumsal ve Siyasal İşlevi Üzerine Bir Değerlendirme. International Journal Of Eurasia Social Sciences, 8(28), 394-407.

Giddens, A. (1998). Modernliğin Sonuçları. İstanbul: Ayrıntı Yayınları. 
Gökalp, Z. (2006). Türkleşmek İslâmlaşmak Muasırlaşmak. Ankara: Akçă̆ Yayınları.

Gündüz, O. (2002). Türkiye'nin Batılllaşma Serüveninde Özgün Bir Portre: Ahmet Hamdi Tanpınar. Uludă Üniversitesi Fen-Edebiyat Fakültesi Sosyal Bilimler Dergisi(3), 12-28.

İleri, S. (2008). Sahnenin Dişındakiler. H. İ. Abdullah Uçman (Dü.) içinde, "Bir Gül Bu Karanlıklarda" (s. 221-224). İstanbul: 3F Yayınevi.

Jeanniere, A. (2000). Modernite Nedir? M. Küçük (Dü.) içinde, Modernite Versus Postmodernite (N. Tutal, Çev., s. 95-101). Ankara: Vadi Yayınları.

Kantarcıoğlu, S. (2008). Huzur'da Aydın Tipi. A. Uçman, \& H. İnci (Dü) içinde, "Bir Gül Bu Karanlıklarda" (s. 325-340). İstanbul: 3F Yayınevi.

Kaplan, M. (2008). Saatleri Ayarlama Enstitüsü. A. Uçman, \& H. İnci (Dü) içinde, "Bir Gül Bu Karanlıklarda" Tanpınar Üzerine Yazllar. İstanbul: $3 \mathrm{~F}$ Yayınevi.

Lewis, B. (1998). Modern Türkiye'nin Doğuşu. Ankara: Türk Tarih Kurumu Yayınları.

Mardin, Ş. (2017). Türk Modernleşmesi. İstanbul: İletişim Yayıncılık.

Meriç, C. (2016). Măgaradakiler. İstanbul: İletişim Yayınları.

Moran, B. (2008). Saatleri Ayarlama Enstitüsü. A. Uçman, \& H. İnci (Dü) içinde, "Bir Gül Bu Karanlıklarda" (s. 262-267). İstanbul: 3F Yayınevi.

Naci, F. (2008). Sahnenin Dışındakiler. A. Uçman, \& H. İnci (Dü) içinde, "Bir Gül Bu Karanlıklarda" (s. 229-238). İstanbul: 3F yayınevi.

Okay, M. O. (2010). Tanpınar, Ahmet Hamdi. Türkiye Diyanet Vakfi İslâm Ansiklopedisi (Cilt 39, s. 567-570). içinde Ankara: Türkiye Diyanet Vakfi Yayınları.

Özgür, N. (2010). Modernleşme ve Aydın Kavramları Çerçevesinde Edebiyat Bağlamında Aykırı Eserler Veren Romanc1/Aydınlar. Ístanbul Bilgi Üniversitesi Sosyal Bilimler Enstitüsü, s. 31.

Said, E. (2015). Entelektüel. İstanbul: Ayrıntı Yayınları.

Tanpınar, A. H. (2014). Huzur. İstanbul: Dergâh Yayınları.

Tanpınar, A. H. (2015c). Beş Şehir. İstanbul: Dergâh Yayınları. 
Tanpınar, A. H. (2015a). Saatleri Ayarlama Enstitüsü. İstanbul: Dergâh Yayınlar1.

Tanpınar, A. H. (2015b). Sahnenin Dışındakiler. İstanbul: Dergâh Yayınları.

Tanpınar, A. H. (2016). Mahur Beste. İstanbul: Dergâh Yayınları.

Tecer, A. K. (1963, Ocak 24). Saatleri Ayarlama Enstitüsü. Cumhuriyet, s. 2.

Ülken, H. Z. (2015). Türkiye'de Çăgdaş Düşünce Tarihi. İstanbul: Türkiye İş Bankası Kültür Yayınları. 